\title{
Correction to: Perfusion imaging of neuroblastoma and nephroblastoma in a paediatric population using pseudo-continuous arterial spin-labelling magnetic resonance imaging
}

\author{
Anita Harteveld ${ }^{1,2}$ D $\cdot$ Annemieke Simone Littooij ${ }^{1,3} \cdot$ Max Maria van Noesel $^{3} \cdot$ Marijn van Stralen $^{1} \cdot$ Clemens Bos $^{1}$
}

Published online: 1 September 2021

(c) The Author(s) 2021

\section{Correction to: \\ Magnetic Resonance Materials in Physics, Biology and Medicine \\ https://doi.org/10.1007/s10334-021-00943-y}

The original version of this article unfortunately contained a mistake. First author name was incorrectly written as Anita Adriaantje Harteveld.

Author name should be Anita Harteveld.

Open Access This article is licensed under a Creative Commons Attribution 4.0 International License, which permits use, sharing, adaptation, distribution and reproduction in any medium or format, as long as you give appropriate credit to the original author(s) and the source, provide a link to the Creative Commons licence, and indicate if changes were made. The images or other third party material in this article are included in the article's Creative Commons licence, unless indicated otherwise in a credit line to the material. If material is not included in the article's Creative Commons licence and your intended use is not permitted by statutory regulation or exceeds the permitted use, you will need to obtain permission directly from the copyright holder. To view a copy of this licence, visit http://creativecommons.org/licenses/by/4.0/.
Publisher's Note Springer Nature remains neutral with regard to jurisdictional claims in published maps and institutional affiliations.

The original article can be found online at https://doi.org/10.1007/ s10334-021-00943-y.

Clemens Bos

c.bos@umcutrecht.nl

1 Department of Radiology, University Medical Centre Utrecht, Utrecht University, P.O. box 85500, 3508 GA Utrecht, The Netherlands

2 Department of Radiology and Nuclear Medicine, Erasmus MC University Medical Centre Rotterdam, Rotterdam, The Netherlands

3 Princess Máxima Centre for Paediatric Oncology, Utrecht, The Netherlands 